Summer 2010

\title{
Who's Responsible for This? The Globalization of Healthcare in Developing Countries
}

Joshua P. Reading

Indiana University Maurer School of Law

Follow this and additional works at: https://www.repository.law.indiana.edu/ijgls

Part of the Health Law and Policy Commons, and the International Trade Law Commons

\section{Recommended Citation}

Reading, Joshua P. (2010) "Who's Responsible for This? The Globalization of Healthcare in Developing Countries," Indiana Journal of Global Legal Studies: Vol. 17 : Iss. 2 , Article 11.

Available at: https://www.repository.law.indiana.edu/ijgls/vol17/iss2/11

This Note is brought to you for free and open access by the Law School Journals at Digital Repository @ Maurer Law. It has been accepted for inclusion in Indiana Journal of Global Legal Studies by an authorized editor of Digital Repository @ Maurer Law. For more information, please contact rvaughan@indiana.edu.

\section{$\Psi$}

JEROME HALL LAW LIBRARY

INDIANA UNIVERSITY

Maurer School of Law
Blooming ton 


\title{
Who's Responsible for This? The Globalization of Healthcare in Developing Countries
}

\author{
JOSHUA P. READING*
}

\begin{abstract}
One aspect of globalization in the developed world is the privatization of services once provided by government. This trend is also arising in developing countries, albeit for different reasons, and an area where this privatization is occurring is healthcare. Despite this privatization, the standard of healthcare in many developing countries is unacceptably low. This Note provides an analysis of this phenomenon in one country-Pakistan, a developing country that has increasingly come to rely on private providers, nongovernmental organizations, and international relief groups for the provision of healthcare-in order to draw conclusions that can be applied elsewhere. While this privatization does serve some needs, it is insufficient to provide an appropriate standard of care to the people of Pakistan. This Note argues that in order to raise the standard of healthcare in developing countries, the flow of privatization should be stemmed in favor of greater government involvement. This involvement includes collaborating with private and international entities, providing better oversight, and supplying financial incentives, in addition to the direct provision of healthcare. With evidence that greater government involvement in the provision of healthcare improves standards of healthcare, this Note concludes that the privatization of healthcare in developing countries should be viewed with caution. Further, there should be an emphasis on increased government involvement to ensure the levels of healthcare to which the people of Pakistan and many other developing countries are entitled.
\end{abstract}

* Senior Managing Editor, Indiana Journal of Global Legal Studies; J.D. Candidate, 2010, Indiana University Maurer School of Law.

Indiana Journal of Global Legal Studies Vol. 17 \#2 (Summer 2010)

(C) Indiana University Maurer School of Law

DOI: 10.2979/GLS.2010.17.2.367 


\section{INTRODUCTION}

Globalization as a trend and an idea wears many masks. One of these masks is the privatization of services traditionally provided by governments. In the United States, this trend of privatization (coupled with the deregulation of certain industries) has been referred to as "new governance." 1 Governments engaging third parties and collaborating with nongovernmental organizations (NGOs) is an aspect of globalization that has taken root in the developed world, especially in the United States. ${ }^{2}$ The relative success of this trend is, however, only one possible outcome of privatization in a developed, stable country. Privatization has also begun to take root in the developing world, but it is occurring there for different reasons than in the developed world (e.g. lack of public resources). This movement should be critically evaluated because while privatization may address some concerns of a developing country, such as lack of funding or administrative capability, the effort can produce negative results if not managed effectively. The privatization of government services in developing countries, in the form of humanitarian intervention, can have unintended consequences. And with the proliferation of NGOs and international groups (including state-affiliated groups), developing states can turn to less traditional, nonstate and international actors to fulfill roles traditionally served by government. This reliance is not necessarily a bad development. In fact, in many areas it is often likely to be beneficial as these new actorswhether international or domestic-may be better equipped to deliver higher quality services. In some circumstances, however, the reliance of a developing state's government on nonstate and international actors may be detrimental to the population, and for this reason privatization should be viewed with caution.

One field that has seen the developing world capitalize on privatization is healthcare. ${ }^{3}$ Privatization, as an aspect of globalization,

1. See Alfred C. Aman, JR., The Democracy Deficit: Taming Globalization THROUGH LAW REFORM 87-90 (2004) (citing in part Lester M. Salamon, The New Governance and the Tools of Public Action: An Introduction, in THE TOOLS OF Government: A Guide to THE NeW Governance 1.2 (Lester M. Salamon ed., 2002) [hereinafter The New Governance]).

2. See generally Lester M. Salamon, The New Governance, supra note 1, at 1; GOVERNMENT BY CONTRACT: OUTSOURCING AND AMERICAN DEMOCRACY (Jody Freeman \& Martha Minnow eds., 2009).

3. See, e.g., Syed Aljunid, The Role of Private Medical Practitioners and Their Interactions with Public Health Services in Asian Countries, 10 HEALTH POL'Y \& Planning 333, 333-35 (1995); Anthony B. Zwi et al., Private Health Care in Developing Countries: If It Is to Work, It Must Start from What Users Need, 323 BRIT. MED. J. 463 (2001), available at http://www.pubmedcentral.nih.gov/articlerender.fcgi?artid=1121065. 
is producing unintended and often unnoticed consequences in the provision of healthcare in developing countries. With few exceptions, national governments are legally obligated to provide a certain standard of healthcare for their citizens, either in their domestic constitution or through international treaty commitments. While private and international groups can provide some relief to a poorer, developing society, the ultimate responsibility of raising the standard of healthcare to an acceptable level falls on the national government. To say that these new actors are better than nothing does not address the fundamental point that the national government should be involved but is not adequately fulfilling its legal obligation. International groups or private entities providing healthcare may be better than nothing, but "nothing" should not be an option. Recently, developing states have come to rely on foreign aid organizations such as the Red Cross, the U.S. Agency for International Development (USAID), Direct Relief, Doctors Without Borders, and others to address not only disaster situations but also basic healthcare needs.

Although the literature in this area is still somewhat scarce, developing states seem to have come to rely heavily on the private sector without providing adequate regulation, oversight, or collaboration. ${ }^{4}$ This reliance coupled with nonstate and international actors' willingness to aid countries in need has led to national governments neglecting their responsibility to provide for and be involved with their citizens' healthcare. Not only should governments be involved with healthcare from a normative and a legal perspective, but there is empirical evidence, provided later in this Note, that increasing government expenditure on healthcare is an effective way to raise the standard of care in a country.

This Note looks at the particular situation of Pakistan-a country that relies heavily on foreign and nongovernmental healthcare providers; a country whose government spends little on healthcare; and a country that has extremely low standards of healthcare. This Note proposes that heavy reliance on the private and international sectors for the provision of healthcare is increasing in developing countries. However, there is a certain minimum level of government involvement that is necessary to meet basic healthcare needs. Many developing countries, such as Pakistan, are not meeting this level of involvement and the standard of healthcare is suffering as a result. Examining the effect that the globalization of healthcare is having on one country and its domestic infrastructure can provide us with conclusions that are applicable to similarly situated developing states. This Note provides

4. See Aljunid, supra note 3, at 341-46. 
some preliminary proposals for how the governments of developing countries can effectively increase their involvement in the provision of healthcare. Pakistan's healthcare situation is not unique: many developing countries are increasingly coming to rely on private healthcare..$^{5} \mathrm{~A}$ study in this area focusing on one country will help us better understand the full implications of healthcare globalization.

\section{LEGAL FOUNDATIONS}

Governments are obligated to provide for the health of their citizens. The methods for fulfilling this obligation vary widely (whether by directly providing health services or by providing oversight and regulation of private entities), but the government needs to be involved in some way. One source of this obligation comes from international law in the form of the Universal Declaration of Human Rights (UDHR). Adopted by the U.N. General Assembly on November 10, 1948, the UDHR is considered part of international customary law, although it is not a legally binding document. ${ }^{6}$ Article 25 of the UDHR addresses healthcare:

Everyone has the right to a standard of living adequate for the health and well-being of himself and of his family, including food, clothing, housing and medical care and necessary social services, and the right to security in the event of unemployment, sickness, disability, widowhood, old age or other lack of livelihood in circumstances beyond his control. ${ }^{7}$

While the UDHR is not legally binding, two later covenants provide the legal enforcement the Declaration lacks: the International Covenant on Civil and Political Rights (ICCPR) and the International Covenant on Economic, Social and Cultural Rights (ICESCR). These documents are binding multilateral treaties, and Pakistan has signed and ratified the ICESCR as of April 17, 2008.8 Article 12 of the ICESCR details the

5. Zwi et al., supra note 3 , at 463 ; see generally Private Health Providers IN Developing CounTRIES (Sara Bennett et al. eds., 1997).

6. Eric A. Posner, Human Welfare, Not Human Rights, 108 CoLUM. L. REv. 1758, 1767 (2008).

7. Universal Declaration of Human Rights, G.A. Res. 217A, art. 25, U.N. GAOR, 3d Sess., 1st plen. mtg., U.N. Doc. A/810 (Dec. 12, 1948) [hereinafter UDHR].

8. See Office of the United Nations High Commissioner of Human Rights, International Covenant on Economic, Social and Cultural Rights, New York, Dec. 16, 1966 , http://treaties.un.org/pages/ViewDetails.aspx?src=TREATY\&mtdsg_no=IV- 
obligations with regard to health, saying that each person has the right of "enjoy[ing] the highest attainable standard of physical and mental health." It goes on to say that steps should be taken to achieve this standard, and it outlines certain specific goals, including the provision of child and birth care, disease prevention, and conditions that allow access to medicine. 10 These responsibilities under the ICESCR are accepted by the large majority of countries in the world, and Pakistan's obligations are not unique.11 Pakistan declared a reservation upon signing the ICESCR that specified that the Covenant was subject to the constitution of the Islamic Republic of Pakistan, but this reservation was later withdrawn. ${ }^{12}$

Islamic countries have criticized the UDHR as having a Western and Judeo-Christian bias, as well as being ignorant of the cultural and religious context of Islamic societies. ${ }^{13}$ However, this rejection of the universality of the UDHR does not affect the analysis with respect to healthcare for multiple reasons. First, Pakistan, a country that is critical of the UDHR, is a signatory to the ICESCR, which has more weight and legal effect than the UDHR. Second, in response to the UDHR, a meeting of the Organisation of the Islamic Conference was called, and this meeting resulted in the Cairo Declaration on Human Rights in Islam. ${ }^{14}$ Article 17 of the Cairo Declaration guarantees a right to medical care and imposes on the state an obligation to provide it. ${ }^{15}$ This Article serves the same end as Article 25 in the UDHR.

Pakistan's constitution also has a provision for healthcare. Article 38 of the Pakistani constitution covers the promotion of the social and economic well being of the people, and subsection (d) says the state shall "provide basic necessities of life, such as food, clothing, housing, education, and medical relief, for all such citizens." 16

3\&chapter=4\&lang=en (last visited Feb. 3, 2010) (showing Pakistan signed the ICESCR on Nov. 3, 2004 and ratified it on April 17, 2008) [hereinafter International Covenant].

9. International Covenant on Economic, Social and Cultural Rights, G.A. Res. 2200A (XXI) art. 12, U.N. Doc. A/6316 (Dec. 16, 1966) [hereinafter ICESCR].

10. Id.

11. Over 160 countries have ratified the ICESCR. See International Covenant, supra note 8 .

12. Id. On April 17, 2008, Pakistan informed the Secretary General that it withdrew its initial reservation.

13. David Littman, Universal Human Rights and Human Rights in Islam, MIDSTREAM, Feb.-Mar. 1999 at 2, available at http://www.dhimmi.org/Islam.html.

14. Organization of the Islamic Conference, 19th Islamic Conference of Foreign Ministers, Resolution 49/19-P (Aug. 5, 1990), available at http://www.oicoci.org/ english/conf/fm/19/19\%20icfm-political-en.htm\#RESOLUTION NO. 49/19-P.

15. Id. art. 17.

16. The Constitution of the Islamic Republic of Pakistan art. 38(d) [1973]. 
As can be seen, both international and domestic laws impose legal obligations on the Pakistani government to provide for the health of its population. These legal sources do not dictate how the obligation should be fulfilled, and any number of methods could be adopted. The problem that will be shown, however, is that Pakistan, as well as other developing states, is not significantly or effectively involved in the provision of healthcare. There is some government expenditure, but it is very low in comparison to other countries in the region and other countries at similar levels of development. Instead, Pakistan predominantly relies on outside providers of healthcare that are unconnected to and have limited contact with the Pakistani government. This globalization, in the form of privatization, has allowed the Pakistani government to remain uninvolved, and the standard of health in Pakistan has failed to improve over time as a result.

\section{HealthCaRe Provision In PaKistaN}

\section{A. Healthcare Providers}

Healthcare is provided in Pakistan by a combination of government expenditure, domestic private parties, and foreign sources. Comparing the level of Pakistan's government healthcare expenditure to the spending of other similarly situated governments, it becomes evident that Pakistan's role in the provision of healthcare is very limited.

One standard measure of government expenditure is the percent of the gross domestic product (GDP) that goes toward healthcare. The World Health Organization (WHO) placed Pakistan's expenditure at two percent of GDP as of 2006.17 Even this assessment may be generous, as one domestic survey of the country's healthcare system put the government's percent expenditure of GDP on healthcare at three quarters of one percent. ${ }^{18}$ This number does not compare well to other similarly situated countries. For comparative analysis, I have chosen two neighboring countries (India and Afghanistan) and a number of other developing countries that have been grouped with Pakistan based on economic development and expected future growth (Egypt, Iran, Nigeria, Mexico, the Philippines, and Bangladesh). ${ }^{19}$ Of these nine

17. World Health Organization, Pakistan, http://www.who.int/countries/pak/en/ (last visited Mar. 24, 2010).

18. Muhammad Akram \& Faheem Jehangir Khan, Health Care Services and Government Spending in Pakistan 1 (Pakistan Inst. of Dev. Econ., Working Paper No. 32 , 2007).

19. The latter group of countries that will be used as a comparison point are members of either the "Next Eleven" or the "D.8" (Developing 8). The Next Eleven are countries 
countries, Pakistan not only has the lowest percent expenditure of GDP on healthcare, but it is also the only country for which this number has steadily decreased since 2000. Each of the eight other countries has maintained or increased its level of government expenditure. In addition to this indicator, other measures of government involvement in the provision of healthcare illustrate the low-level role of the Pakistani government. Table 1 provides a comparison of the countries noted above, based on several different indicators. All of these relevant indicators have been consistently low for Pakistan since 2000. While Pakistan is the focal point of this particular case study, the numbers of the other countries illustrate that low government expenditure on healthcare is common among developing countries, and the lessons that we can derive from Pakistan may thus have broader application.

Table 1

\begin{tabular}{|l|l|l|l|l|l|l|l|}
\hline \multicolumn{7}{|c|}{$\begin{array}{c}\text { General Government Expenditure on Health as } \\
\text { Percentage of Total Expenditure on Health }\end{array}$} \\
\hline Location & 2000 & 2001 & 2002 & 2003 & 2004 & 2005 & 2006 \\
\hline Afghanistan & 1.0 & 1.3 & 8.3 & 11.1 & 16.2 & 20.0 & 27.5 \\
\hline Bangladesh & 26.5 & 26.6 & 26.3 & 28.7 & 29.0 & 29.1 & 36.8 \\
\hline Egypt & 40.1 & 40.1 & 39.8 & 39.5 & 37.9 & 38.0 & 40.7 \\
\hline India & 22.2 & 20.5 & 19.1 & 18.5 & 17.7 & 19.0 & 19.6 \\
\hline Iran & 37.0 & 41.7 & 43.1 & 46.9 & 43.9 & 55.8 & 55.6 \\
\hline Mexico & 46.6 & 44.9 & 43.9 & 44.1 & 46.4 & 45.5 & 43.3 \\
\hline Nigeria & 33.5 & 31.4 & 25.6 & 27.4 & 30.8 & 30.9 & 30.1 \\
\hline Pakistan & 20.0 & 19.7 & 24.2 & 16.6 & 18.5 & 17.5 & 16.4 \\
\hline Philippines & 47.6 & 44.2 & 40.0 & 38.2 & 38.0 & 36.6 & 39.6 \\
\hline United States & 43.7 & 44.6 & 44.6 & 44.5 & 44.8 & 45.1 & 45.8 \\
\hline
\end{tabular}

identified by Goldman Sachs as having the potential to become the world's largest economies in the 21st century. The list was made in 2005. See Jim O'Neill et al., Global Economics Paper No. 134: How Solid Are the BRICs?, Goldman Sachs Economic Research Group (2005), available at http://www2.goldmansachs.com/ideas/brics/how-solid-doc.pdf (last visited Mar. 24, 2010). The D-8 is a group of eight developing countries with large Muslim populations that formed an economic alliance in Turkey in 1997. D-8 Organization for Economic Cooperation, Brief History, http://www.developing8.org/about-d-8/briefhistory/ (last visited Mar. 24, 2010). 
Table 1 cont'd

\begin{tabular}{|c|c|c|c|c|c|c|c|}
\hline \multicolumn{8}{|c|}{$\begin{array}{l}\text { General Government Expenditure on Health as } \\
\text { Percentage of Total Government Expenditure }\end{array}$} \\
\hline & 2000 & 2001 & 2002 & 2003 & 2004 & 2005 & 2006 \\
\hline Afghanistan & 1.1 & 1.1 & 1.2 & 1.5 & 2.1 & 3.3 & 4.4 \\
\hline Bangladesh & 5.3 & 5.8 & 5.6 & 6.4 & 6.2 & 5.5 & 7.4 \\
\hline Egypt & 7.5 & 7.8 & 7.7 & 7.8 & 7.3 & 7.3 & 7.3 \\
\hline India & 3.4 & 3.3 & 3.2 & 3.1 & 3.1 & 3.5 & 3.4 \\
\hline Iran & 9.6 & 11.2 & 11.3 & 7.7 & 7.5 & 9.2 & 9.2 \\
\hline Mexico & 11.4 & 11.9 & 11.6 & 11.7 & 12.9 & 12.5 & 11.0 \\
\hline Nigeria & 4.2 & 3.2 & 3.1 & 3.2 & 3.5 & 3.5 & 3.5 \\
\hline Pakistan & 1.8 & 1.8 & 1.9 & 1.4 & 1.6 & 1.5 & 1.3 \\
\hline Philippines & 7.0 & 6.2 & 5.0 & 5.4 & 5.7 & 5.5 & 6.4 \\
\hline United States & 19.5 & 20.4 & 18.0 & 18.4 & 18.7 & 18.7 & 19.1 \\
\hline \multicolumn{8}{|c|}{$\begin{array}{l}\text { Total Expenditure on Health as } \\
\text { rcentage of Gross Domestic Product }\end{array}$} \\
\hline & 2000 & 2001 & 2002 & 2003 & 2004 & 2005 & 2006 \\
\hline Afghanistan & 3.3 & 3.3 & 3.6 & 4.4 & 4.4 & 5.2 & 5.4 \\
\hline Bangladesh & 3.1 & 3.2 & 3.1 & 3.1 & 3.1 & 2.8 & 3.1 \\
\hline Egypt & 5.6 & 6.0 & 6.3 & 6.4 & 6.1 & 6.1 & 6.3 \\
\hline India & 4.3 & 4.6 & 4.8 & 4.8 & 4.9 & 5.0 & 4.9 \\
\hline Iran & 5.9 & 6.1 & 6.1 & 6.2 & 6.2 & 7.8 & 7.8 \\
\hline Mexico & 5.6 & 6.0 & 6.2 & 6.3 & 6.5 & 6.4 & 6.2 \\
\hline Nigeria & 4.3 & 5.3 & 5.0 & 4.7 & 4.0 & 3.9 & 4.1 \\
\hline Pakistan & 2.5 & 2.3 & 2.3 & 2.2 & 2.2 & 2.1 & 2.0 \\
\hline Philippines & 3.5 & 3.2 & 3.0 & 3.3 & 3.3 & 3.2 & 3.3 \\
\hline United States & 13.2 & 13.9 & 14.7 & 15.1 & 15.2 & 15.2 & 15.3 \\
\hline
\end{tabular}

Source: WHO Statistical Information System, http://www.who.int/ whosis/en/index.html (last visited Feb. 3, 2010). The charts were created by conducting a detailed search in the categories desired with the countries selected for the years 2000-06.

Turning to the private sector, one study indicates that eighty percent of outpatient services in Pakistan are provided by the private sector. In addition, seventy-seven percent of the households in Pakistan consult private providers of healthcare, while only twenty-three percent 
rely on public providers. ${ }^{20}$ This private sector dominance is not necessarily a bad thing in itself. The utilization of private healthcare service providers in developing countries has been encouraged by international policy makers for a variety of reasons. For example, the government can focus on its role as a regulator and guarantor of the provision of healthcare. ${ }^{21}$ Doubts are raised, however, as to whether the government is fully taking on its role of regulation and oversight when so little is being spent on healthcare.

While the breakdown of private versus public providers for each comparison country was not compiled for this study, the division between private and public providers of healthcare is generally similar. Private providers play a significant role in healthcare markets in developing countries.22 The specific figures demonstrating this phenomenon are not critical. The important point is that if the government is not providing healthcare, it must at least be involved by regulating and monitoring the private sector or by contracting with private providers. As the numbers above and other evidence below demonstrate, the Pakistani government and other developing countries are not adequately performing this task. The end result is an unacceptably low standard of health.

Finally, as shown in Table 2 below, Pakistan and a number of other developing countries rely heavily on external healthcare providers. While a developed country such as the United States may have zero percent of its healthcare coming from foreign providers, and some developing countries will have below one percent, Pakistan and other countries have a more substantial amount of healthcare coming from the outside. Perhaps more significant, however, is the increasing or stable level of spending by external providers in countries like Afghanistan, Bangladesh, Egypt, Nigeria, Pakistan, and the Philippines.

20. Akram \& Khan, supra note 18 , at 12.

21. See Zwi et al., supra note 3 , at 463 .

22. See, e.g., Private Health Providers in Developing Countries, supra note 5; see also Private Healthcare in Developing Countries, Homepage, http://ps4h.org/ (last visited Mar. 24, 2010). 
Table 2

\begin{tabular}{|l|l|l|l|l|l|l|l|}
\hline \multicolumn{7}{|c|}{ External Resources for Health as } \\
\hline Location & 2000 & 2001 & 2002 & 2003 & 2004 & 2005 & 2006 \\
\hline Afghanistan & 1.9 & 3.2 & 3.8 & 6.4 & 5.9 & 13.1 & 20.1 \\
\hline Bangladesh & 19.4 & 14.9 & 13.8 & 15.5 & 14.9 & 12.2 & 14.6 \\
\hline Egypt & 1.0 & 0.9 & 0.8 & 0.7 & 0.9 & 0.9 & 0.8 \\
\hline India & 0.6 & 2.4 & 0.3 & 0.6 & 0.5 & 0.4 & 0.7 \\
\hline Iran & 0 & 0.4 & 0.2 & 0.2 & 0.1 & 0.1 & 0.1 \\
\hline Mexico & 1.0 & 0.9 & 0.7 & 0 & 0 & 0 & 0 \\
\hline Nigeria & 16.2 & 5.6 & 6.1 & 3.2 & 4.0 & 4.8 & 5.9 \\
\hline Pakistan & 0.9 & 1.4 & 1.8 & 2.2 & 2.5 & 3.6 & 3.2 \\
\hline Philippines & 3.5 & 3.7 & 2.8 & 3.4 & 4.0 & 5.1 & 3.3 \\
\hline United States & 0 & 0 & 0 & 0 & 0 & 0 & 0 \\
\hline
\end{tabular}

Source: WHO Statistical Information System, http://www.who.int/ whosis/en/index.html (last visited Feb. 3, 2010). This chart was created by doing a detailed search in the category (external resources for health) with the countries selected for the years 2000-06.

Some of the more well known organizations active in Pakistan include Doctors Without Borders, USAID, the International Committee of the Red Cross (ICRC), and Direct Relief. In addition, a number of other international donors are involved with more specialized relief efforts. For example, a host of international organizations contribute to family planning efforts throughout Pakistan, including groups from the United Nations, the United Kingdom, Sweden, and Canada. ${ }^{23}$

Pakistan especially relies on foreign donors during disaster situations. In October 2005, Pakistan was hit by a massive earthquake that measured 7.6 on the Richter scale. It killed an estimated seventysix thousand people. ${ }^{24}$ The government was involved in initial relief efforts, particularly in improving access to areas cut off due to the damaged infrastructure, but the local health infrastructure was quickly overwhelmed by the scale of the disaster. ${ }^{25}$ International relief efforts

23. See Hilda Saeed, Pakistan, in The Right to KNOw: Human RIGHTS AND ACCESS TO REPRODUCTIVE HEALTH INFORMATION 231, 243 (1995).

24. DOCTORS WITHOUT BORDERS, INTERNATIONAL ACTIVITY REPORT: PAKISTAN (2006), available http://doctorswithoutborders.org/publications/ar/report.cfm?id=2010\&cat=activity-report.

25. Id. 
were necessary for the government to be able to adequately respond to the situation. After four years, international assistance is still coming into Pakistan to relieve the suffering caused by the earthquake. Direct Relief has contributed over $\$ 14$ million to help rebuild the local healthcare infrastructure. ${ }^{26}$ USAID has provided $\$ 510$ million in support of earthquake relief and has contributed to the actual provision of healthcare through its partner, Mercy Corps. ${ }^{27}$ Doctors Without Borders, ICRC and its affiliates, and other organizations were heavily involved in relief efforts as well. ${ }^{28}$

On October 29, 2008, a series of earthquakes struck Balochistan, a large province in Pakistan, resulting in another disaster situation. Again, the government responded initially, but the response was insufficient, ${ }^{29}$ and Pakistan relied heavily on foreign providers for relief and healthcare. As expected, many of the same organizations were involved. The ICRC provided substantial material support to relief efforts, ${ }^{30}$ Direct Relief and the American Refugee Committee mobilized staff and offered medical aid, ${ }^{31}$ and Doctors Without Borders set up medical clinics and distributed supplies. ${ }^{32}$

International aid is to be expected in response to natural disasters, especially in developing countries. However, a survey of the relief efforts in response to these particular disasters raises doubts about the Pakistani government's commitment and capacity to provide healthcare for its citizens in the form of disaster relief. In fact, some groups have blamed the Pakistani government for a slow response time, resulting in

26. Direct Relief International, Earthquake Response - Pakistan, Oct. 8, 2008, http://www.directrelief.org/EmergencyResponse/2005/EarthquakePakistan.aspx?gclid=CO i_pKTFr5gCFRwpawod7GZ_UA.

27. Embassy of the United States, USAID Provides Health Care Close to Home, Feb. 24, 2006, available at http://islamabad.usembassy.gov/pakistan/h06022401.html.

28. For a more complete survey of the extent of international organizations efforts in response to the 2005 earthquake, see ReliefWeb, South Asia: Earthquake - Oct. 2005, http://www.reliefweb.int/rw/dbc.nsf/doc108?OpenForm\&emid=EQ-2005-000174-

PAK\&rc=3 (last visited Mar. 24, 2010).

29. See BBC News, Pakistan Survivors Wait for Aid, Oct. 30, 2008, available at http://news.bbc.co.uk/2/hi/south_asia/7699056.stm.

30. International Committee of the Red Cross, ICRC Response to Baluchistan Quake: Operational Update, Nov. 8, 2007, http://www.icrc.org/Web/Eng/siteeng0.nsf/htmlall/ pakistan-update-081108.

31. Direct Relief International, Earthquake Response - Pakistan, Oct. 29, 2008, http://www.directrelief.org/EmergencyResponse/2008/EarthquakePakistan.aspx?linkidenti fier=id\&itemid $=4012$.

32. Doctors Without Borders, Pakistan Earthquake: MSF Teams Assisting WorstAffected Population, Oct. 30, 2008, http://doctorswithoutborders.org/news/article.cfm?id= $3164 \&$ cat $=$ field-news\&ref $=$ tag-index. 
unnecessary deaths. ${ }^{33}$

These different elements-the low level of government expenditure, the inadequacy of the public sector, or alternatively the inadequacy of the regulation of the private sector, and reliance on international healthcare providers-establish that the government is not fulfilling its legal obligation (both international and domestic) to provide for the health of its citizens. Next the standard of health in Pakistan is analyzed to assess the results of the privatization and outsourcing of healthcare in developing countries.

\section{B. Healthcare Standards}

There are a number of different ways to measure a country's standard of health. This Note utilizes some of the more traditional health indicators, as well as other assessments and individual studies. Pakistan's average life expectancy has been reported as between sixtytwo and sixty-four years of age. ${ }^{34}$ The number of children that die before reaching age five per 1,000 children has been reported between 97 and $123 .{ }^{35}$ One domestic report found that of the children that do survive until age five, forty percent suffer from malnutrition. ${ }^{36}$ A Human Development Report, issued by the U.N. Human Development Programme, lists the probability of not surviving past the age of forty at 12.6 percent, which ranks 97 th out of 177 countries. ${ }^{37}$ WHO lists Pakistan's infant mortality rate for 2006 at seventy-eight out of every 1,000 births. ${ }^{38}$ Another significant indicator is the Human Development Index (HDI) issued through the Human Development Reports. HDI takes into account other factors, primarily education and economic wellbeing, in addition to a variety of health indicators. While the number does not focus exclusively on healthcare, it is worth noting that for a country that has been considered one of the "Next Eleven," 39 Pakistan

33. See International Crisis Group, Pakistan: Political Impact of the Earthquake, March 15, 2006, http://www.crisisgroup.org/home/index.cfm?id=4023\&l=1.

34. World Health Organization, supra note 17 (giving the life expectancy for males as 62 and for females as 63); $c f$. HUMAN DEVELOPMENT REPORT 2009, PAKISTAN, available at http://hdrstats.undp.org/en/countries/country_fact_sheets/cty_fs_PAK.html (last visited Mar. 24, 2010) (giving the average life expectancy as 66.2 years, which ranks 117 th out of 177 countries) [hereinafter HUMAN DEVELOPMENT REPORT].

35. World Health Organization, supra note 17 (reporting that 97 per 1,000 children die before age five); cf. Akram \& Khan, supra note 18, at 2 (reporting that 123 per 1,000 children die before age five).

36. Akram \& Khan, supra note 18 , at 2.

37. HUMAN DEVELOPMENT REPORT, supra note 34.

38. World Health Organization, supra note 17.

39. See O'Neill, et al., supra note 19. 
ranks 141st out of 177 countries indexed.40

Care for mental health in Pakistan is also poor. Stigmas are attached to mental illness, similar to the situation of the United States in the eighteenth century, and much of the population still relies on shamanic and spiritual medicine to treat mental disorders. ${ }^{41}$ In fact, even though the Pakistani government repealed dated and inadequate legislation in the area (the Lunacy Act of 1912), its replacement-the Mental Health Ordinance-has yet to be implemented despite being enacted in 2001.42

In addition to its overall low standard of health, other problems exist. One major problem facing Pakistan is the disparity between urban and rural healthcare. The larger cities in Pakistan-Karachi, Lahore, and Islamabad-enjoy greater access to healthcare facilities, higher quality methods, and more specialized forms of healthcare than rural areas of the country. This divide, which is at the same time a socioeconomic divide between the wealthy portions of Pakistan's society and its poorer agrarian portions, is widely recognized..$^{43}$ Also, due to the political instability in the northern parts of the country, a civilian displacement crisis is occurring in the rural areas, and Doctors Without Borders is one agency that is addressing the situation in the wake of the initial government response failing to keep up with the increasing needs of displacement camps. ${ }^{44}$

Sources from the U.N. and WHO, among others, can be accessed for a full survey of the multitude of available health indicators. For the purposes of this examination, however, the information presented demonstrates that the level of healthcare in Pakistan is very low. While this fact may not seem surprising given its status as a developing

40. HuMAN DEVElopMENT REPORT, supra note 34 (showing the top rated country, Norway, has an HDI of .971, while Niger, ranked 182nd, has an HDI of .340).

41. See Christine A. Kelly-Miller, The Influence of Culture, Government and the Law on the Use of Antidepressants for Children in the United States and Pakistan, 63 FoOD \& DRUG L.J. 713, 714-16 (2008).

42. $I d$. at 715 .

43. See, e.g., Akram \& Khan, supra note 18, at 21; see also Saeed, supra note 23, at 234-35 (discussing the lack of family planning services and information available to the rural populations). For statistical information, the WHO Statistical Information System can be utilized to highlight the lower standard of healthcare in rural areas as compared to urban areas. WHOSIS can be accessed at http://www.who.int/whosis/en/index.html, and tables can be created for Pakistan with specific categories on rural vs. urban numbers.

44. See Doctors Without Borders, Top Ten Humanitarian Crises of 2008: Civilians Killed and Forced to Flee as Fighting Intensifies in Northwestern Pakistan, http://doctorswithoutborders.org/publications/topten/2008/story.cfm?id=3238 (last visited Mar. 24, 2010); see also Doctors Without Borders, Top Ten Humanitarian Crises of 2008: Pakistan: Trying to Meet the Needs of the Displaced, Oct. 29, 2008, http://doctorswithoutborders.org/publications/topten/2008/article.cfm?id=3159. 
country, the point to be taken is that poor healthcare does not necessarily flow from Pakistan's current economic situation. Pakistan is considered a promising developing country: it has developed nuclear technology, and there is substantial money being spent domestically, just not on infrastructure or social programs.45 This latter point is bolstered by the evidence presented above that Pakistan is not spending enough on the country's healthcare, whether for direct provision of healthcare or for regulation of the private sector.

While the level of government spending is indirect evidence of its lack of involvement with the industry, there is also some direct evidence that the government is neglecting its responsibility in this area. In addition to not implementing the provisions of the Mental Health Ordinance, Pakistan's Ministry of Health is minimally involved in drug authorization and warnings. 46 Many healthcare providers rely on information from pharmaceutical companies regarding drugs and their possible side effects. A 2007 study published in the Journal of Medical Sciences (a Pakistani publication) listed the side effects of certain antidepressants used to treat attention deficit/hyperactivity disorder as drowsiness, dry mouth, constipation, and sleep disturbances, along with other minor side effects. ${ }^{47}$ The same antidepressants were given a black box warning by the Food and Drug Administration of the United States in 2004 because the drugs increased suicidal tendencies in children and adolescents. ${ }^{48}$ Further, while Pakistan is a signatory to the U.N.'s Millennium Development Goals project, a domestic report on its progress-Medium Term Development Framework-reported that lack of regulation of the healthcare industry remains a major issue facing Pakistan. ${ }^{49}$

The point is not that Pakistan should be meeting the standards of health enjoyed by the United States or other developed countries. The purpose of the comparison presented earlier in the Note is to place Pakistan next to countries that are similarly situated, both economically and socially. Even in that context, the government is underperforming its counterparts, and the country is suffering as a result. This observation is not made to single out Pakistan but to draw the correlation between the lack of government involvement and the

45. See, e.g., Hassan Abbas, Pakistan Through the Lens of the "Triple-A Theory," 30 FLETCHER F. WORLD AFF. 181, 190-91 (2006) (saying that the substantial amount of money that has been dedicated to the military has been to the detriment of healthcare and infrastructure, and as a result has perpetuated the low standard of living of the majority of the country).

46. See Kelly-Miller, supra note 41 , at 720-21.

47. Id. at 721 .

48. Id.

49. Akram \& Khan, supra note 18 , at 8 . 
problems Pakistan is experiencing in healthcare. Although Pakistan's numbers are below some of the comparison countries' figures, those countries' numbers are also low, and these same lessons should be applied to other developing countries with similar healthcare situations.

The factors this Note examines-the low level of expenditure and the inadequate government response to certain situations-illustrate that fulfilling the legal obligation in regard to healthcare is not a priority of domestic policy. While reliance on globalized healthcare may be understandable, the effects of reliance on private or international healthcare providers are generally negative, and positive change is not evident. The question then becomes, what can be done? Optimistically, there is evidence suggesting that increased government expenditure improves the quality of healthcare. Further, there is proof of this in Pakistan. The following proposals are made with the understanding that any developing country's budget is going to be strained. However, this obstacle does not take away from the important point that even a small increase in involvement by the government and the ownership of its responsibility will improve healthcare in the country.

\section{PROPOSALS FOR REFORM}

Considering the legal foundations set out above and the current lack of government involvement in healthcare, the general framework for these proposals will be concerned with increasing government expenditure and programs. The state is obligated to ensure access to quality healthcare for its citizens. This involves not only more programs originating with the government, but also greater regulation of the private healthcare service sector and better oversight of the drugs being provided. There should also be greater incentives for international providers of healthcare to collaborate more effectively with governments. Finally, improved communication and cooperation between the international community and domestic governments in the regulation of drug providers and access to medicines in developing countries are also needed. This latter point regarding international drug regulation is one that deserves more comprehensive coverage elsewhere, but the point is worth a brief mention here in light of the direct-toconsumer marketing that is occurring in developing countries and the fact that these governments often rely on information from drug providers. 


\section{A. Government Expenditure and Programs}

There is evidence that increased government expenditure leads to an increased quality of national healthcare, although this point is debated. ${ }^{50}$ Although some government inefficiency is inevitable, countries that spend more on healthcare have higher standards of health. Government expenditure is surely not the only factor giving rise to some countries' higher standards of health, but the consistent correlation cannot be dismissed as mere coincidence.

Another issue to be considered is how the benefits of government expenditure on healthcare are allotted. Keeping in mind the point above regarding the divide between the quality of healthcare in urban versus rural locales, a study done by the Pakistan Institute for Development Economics also acknowledges that public expenditure generally benefits the urban and wealthier sectors of the population. ${ }^{51}$ Despite potential inequities, however, it is important that Pakistan raise its level of public expenditure on healthcare. The rural-urban divide is one that cannot be ignored and that will require continued attention, but this issue should not be an excuse for the government to continue its practice of under-supporting the healthcare industry. In fact, it appears the government acknowledges the need for increased expenditure in rural areas, at least on the provincial level. Following the 2005 earthquake, the governments of the Northwest Frontier Province and Sindh increased their health budgets. ${ }^{52}$ Provincial or local action by itself will not be enough, but it signifies an awareness of government authority that the standard of health (and particularly disaster response capability) was too low and that one way to address this problem is by increased government expenditure.

In addition to increasing public spending in healthcare, using a portion of those funds for specific government programs is also an effective way for the government to assist and improve the provision of healthcare. Optimistically, there is evidence of this occurring in Pakistan. In 1993, Pakistan undertook a new approach to providing family planning information and services to women in rural Pakistan. The program focused on training literate, married women living in rural

50. See, e.g., id. at 3 (stating that the share of health expenditure of total public expenditure is the most important variable affecting the standard of health in a country, but conceding that other studies have failed to find an empirical link between the two.)

51. Id. (citing studies done in the United Kingdom and Africa in which it was found that poorer populations benefit less from government expenditure on healthcare).

52. Global Insight, Provincial Authorities Increase Health Budgets in Pakistan, But No Sign of a Comprehensive Federal Strategy, http://www.globalinsight.com/SDA/SDA Detail6176.htm (last visited Mar. 24, 2010). 
areas to meet with and educate illiterate and uneducated women in local villages about family planning and the healthcare options available to them. ${ }^{53} \mathrm{~A}$ study of the results of this government program found that the method was well suited to the social and cultural conditions of rural Pakistan; that it was effective and increased the likelihood of rural families utilizing modern contraceptives; and that the program should be expanded to address the needs of Pakistan's rural population. ${ }^{54}$ Another example of an effective government program is the Measles Initiative, an international partnership devoted to improving access to measles vaccines and reducing the number of measles deaths around the world.55 With support from the Measles Initiative, the government of Pakistan led a campaign to immunize children across the country. In the first phase, the effort successfully reached ninety-six percent of the target group. ${ }^{56}$ Both of these programs are evidence that the government of Pakistan is fully capable of meeting the healthcare needs of its citizens. Tactical support may be required from international donors, but the government is the entity that is often best equipped to implement and deliver these programs.

\section{B. Regulation and Collaboration with the Private Sector}

Government regulation of the private healthcare sector also needs improvement. Private healthcare makes up the substantial majority of healthcare provision in Pakistan, as noted above, and largely serves the wealthier portions of the population. One proposed reform is incentivizing private healthcare providers to serve the poor and underserved as well as the wealthy. These incentives could take the form of financial benefits similar to the preferential tax treatment that nonprofit organizations receive in the United States, or they could involve granting state funds and resources with the requirement that they go toward providing healthcare for the poor.

Room for improvement also exists in educating the rural and uninformed population regarding the availability of primary healthcare centers in their areas. Many people in Pakistan still rely on magical,

53. See Mehboob Sultan et al., Assessment of a New Approach to Family Planning Services in Rural Pakistan, 92 AM. J. PUB. HEALTH 1168, 1168 (2002).

54. Id. at 1171-72.

55. See Measles Initiative, http://www.measlesinitiative.org/ (last visited Mar. 24, 2010).

56. American Red Cross, New Phase of Largest-Ever Measles Vaccination Campaign Begins in Pakistan, June 28, 2007, http://www.redcross.org/portal/site/en/menuitem.94 aae335470e233f6cf911df43181aa0/?vgnextoid=203bb4c1fb1cb110VgnVCM10000089f0870a RCRD\&vgnextfmt=default. 
spiritual, or shamanic methods for curing illnesses, ${ }^{57}$ and the government should sponsor programs aimed at educating the population about modern healthcare and the public and private options available to them. A program with this goal could easily mirror the family planning program that was successful in the 1990s. A successful effort in this area would increase the burden on the already struggling healthcare sector, both private and public. The fact that improved access to healthcare facilities will bring additional demand underscores the need for the government to increase expenditure and make resources available to private providers of healthcare.

Finally, as a related point, the Ministry of Health should be more involved and provide greater oversight of the medications available in Pakistan. The fact that a class of antidepressants that received a black box warning from the FDA was promoted as a low-risk option for mental health treatment indicates that the government is not adequately performing its duty. Even if the Pakistani government were to simply rely on reports from the FDA, this would be an improvement in the domestic regulation of the drugs available in Pakistan.

The government should also be providing incentives to international and nonstate healthcare providers to collaborate more fully with the government and to attempt to reach a wider sector of the population. In a study covering six developing countries, including Pakistan, it was found that collaboration generally occurs on specialized or occasional projects, as opposed to a general plan of interaction between the government and nongovernmental providers. ${ }^{58} \mathrm{~A}$ general collaborative plan between government officials and international or other nonstate providers might be difficult on a practical level, but the benefits for healthcare providers would be increased access to resources and regions, and the benefits for the government would be regular oversight and quality control.

An example of such a successful collaboration is the Green Star organization in Pakistan. The government of Pakistan encouraged Green Star to get accredited in exchange for receiving grants. In return, Green Star established relationships with healthcare providers; Green Star trained the providers and required them to deliver services of a certain kind and quality consistent with Green Star's accreditation. Provider training and provision of healthcare were monitored by regular visits from Green Star and clients reporting back to the organization. ${ }^{59}$

57. See Kelly-Miller, supra note 41, at 715-16; see also Akram \& Khan, supra note 18, at 13 .

58. Natasha Palmer, An Awkward Threesome - Donors, Governments, and Non-state Providers of Health in Low Income Countries, 26 PUB. ADMIN. DEV. 231, 234 (2006).

59. Id. at 236 . 
A study of the Green Star network concluded that the private sector was capable of providing quality healthcare given the right incentives and resources by the government. ${ }^{60}$

Contracting with international providers of healthcare is another way for the government to contribute to the provision of healthcare. If an international group is deemed more qualified to deliver effective and efficient healthcare, the government could contribute to the international provider the portion of its budget that was already allocated to that particular service area in order to assist the international group in providing that service. This monetary collaboration would also allow the domestic government to have a greater say in how the healthcare is provided. The government could also provide access to facilities previously used by the government for the same or similar services. There is no reason for the government simply to step aside and allow the international or nonstate group to shoulder the burden. This method of collaboration has already seen some success in developing countries, including Pakistan. ${ }^{61}$

These suggestions demonstrate that there are a host of options for the government to remain involved on a long term scale with international and other nonstate providers of healthcare. Enacting some of these methods may be difficult, but some effort is certain to improve the quality and reach of the services being provided by these groups. Again, this Note does not urge that the government should always be the provider of healthcare, because the private sector or international groups may be better equipped for the actual delivery of services. However, financial and resource support from the government, in addition to regulation, are fundamental to ensuring that the population has access to quality healthcare.

Lastly, the international community can also serve a greater role in the regulation of drug providers in developing and low income countries. This topic is outside the scope of this Note, but the task of regulating and approving each drug entering the country may be too much of a burden for a developing country's government to bear alone. The Pakistani government has had lapses and needs to improve its own regulation of drugs and medicines, but just as with international healthcare providers, international agencies should help alleviate some of the risk by preventing dangerous or unapproved drugs from entering

60. Id. (citing J. McBride \& R. AHMED, SOCial Franchising as STRATegY For

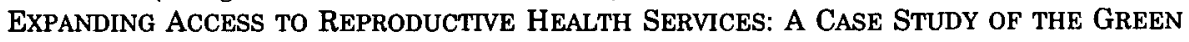
STAR SERVICE DELIVERY NETWORK IN PAKISTAN (2001)).

61. See id. at $237-38$. 
the markets of low income countries. ${ }^{62}$

The point here is not shifting the burden to international entities, but as proposed earlier, increasing cooperation between domestic governments and international agencies in the area of drug regulation. The problem of improving the standard of healthcare in developing countries like Pakistan is not going to be solved by the domestic government alone. International organizations should help to ensure that countries meet international legal healthcare obligations. This responsibility could be met, in part, by monitoring the drugs provided in developing countries, in terms of quality, safety, access and pricing.

\section{CONCLUSION}

This Note examines one developing country's healthcare system as an example of some of the effects of the globalization of healthcarenamely, privatization and domestic government reliance on international and nonstate providers. There is a legal foundation for the claim that national governments should be responsible for and involved with the provision of healthcare. This legal obligation comes from international law and sometimes also from domestic law. The recognition of this obligation means that although the proposals offered here are primarily for domestic reform, the international community cannot consistently ignore unacceptably poor levels of healthcare in countries with which it interacts.

As has been stressed throughout this Note, insisting that a government fulfill its legal obligation to provide healthcare for its population does not mean socializing healthcare or that the government should be the actual provider of healthcare. Outsourcing and contracting with private entities is one alternative, and privatization is the aspect of globalization that has been the focus of this Note. Regulation and oversight are other avenues for the government to ensure its citizens have access to quality healthcare. The common thread running throughout these suggested reforms is that with increased government involvement, the level of healthcare will improve, both in terms of access and quality: increased expenditure leads to improved healthcare. Government programs with proper support are successful in achieving their goals, and regulating and providing

62. For a deeper discussion of the issue of access to drugs and pricing, see, e.g., Tina $\mathrm{S}$. Bhatt, Note, Amending TRIPS: A New Hope for Increased Access to Essential Medicines, 33 BRookLYN J. INT'L L. 597 (2008); see also Peggy B. Sherman \& Ellwood F. Oakley, III, Pandemics and Panaceas: The World Trade Organization's Efforts to Balance Pharmaceutical Patents and Access to AIDS Drugs, 41 AM. BUS. L.J. 353 (2004). 
incentives to private providers improves the quality of care delivered by the private sector. This evidence is compelling, but the situation continues to be that the governments of developing countries rely on the private sector, interact only occasionally with international providers, and spend little on healthcare. The unintended, negative consequences of this trend are also compelling. While this Note is primarily concerned with Pakistan's low standard of healthcare, WHO, the U.N., and other organizations provide evidence that low healthcare standards are prevalent across the globe in developing countries.

The increased government responsibility that this Note proposes is not the cure-all for improving the level of healthcare in the developing world. It is, however, a response to at least one impact of globalization in the area of healthcare. In the end, the state is the guarantor of its population's health, and adequate standards will not be reached without government involvement and oversight. Increasing government involvement in healthcare in developing countries is one way to help ensure that this fundamental right is not discarded in the face of globalization and other demands facing developing countries in the twenty-first century. 
